\title{
KINETIC MODELLING OF CONTINUOUS-MIX ANAEROBIC REACTORS OPERATING UNDER DIURNALLY CYCLIC TEMPERATURE ENVIRONMENT
}

\author{
${ }^{1}$ Echiegu, E.A. and ${ }^{2}$ A.E. Ghaly \\ ${ }^{1}$ Department of Agricultural and Bioresources Engineering, University of Nigeria, Nsukka, Nigeria \\ ${ }^{2}$ Department of Biological Engineering, Faculty of Engineering, Dalhousie University, Halifax, Canada
}

Received 2014-07-18; Revised 2014-07-18; Accepted 2014-08-18

\begin{abstract}
A two-culture dynamic model which incorporated the effects of diurnally cyclic temperature was developed and used to predict the dynamic response of anaerobic reactors operated on dairy manure under two diurnally cyclic temperature ranges of $20-40^{\circ} \mathrm{C}$ and $15-25^{\circ} \mathrm{C}$ which represent the summer and winter in Nigeria. The digesters were operated at various hydraulic retention times and solid concentrations and some useful kinetic parameters were determined. The model predicted biogas production, volatile solid reduction, methane yield and treatment efficiency with reasonable accuracy $\left(\mathrm{R}^{2}=0.70\right.$ to 0.90$)$. The model, however, under-predicted the cell mass concentration in the reactor probably because the Volatile Suspended Solid (VSS), which was used as the estimator of the actual cell mass concentration in the reactor, was not a good indicator of the active cell mass concentration in anaerobic reactors operating on dairy manure.
\end{abstract}

Keywords: Kinetic Modeling, Anaerobic Reactor, Diurnally Cyclic Temperature, Continuous Mix Reactors

\section{INTRODUCTION}

Diurnally cyclic variation in slurry temperature is a common phenomenon in anaerobic reactors operated under ambient conditions. Empirical studies have shown that under a diurnally cyclic temperature environment, gas production as well as some other operating and performance indices follow a diurnally cyclic pattern with some lag relative to the environmental temperature (Ghaly and Echiegu, 1993; Ghaly and Alhattab, 2011). Thus, there is a need to develop a kinetic model capable of predicting the behaviour of reactors operated under this condition.

The primary purpose of kinetic modeling of the anaerobic fermentation processes is to predict the digester performance under varying operating conditions. Based on the kinetic expression used to describe cell growth, three basic kinetic models have significantly contributed towards the understanding of animal waste digestion. These are: The First Order Models (Moris, 1976), Monod based Models (Hill and Barth, 1977) and Conto is Based Models (Chen and Hashimoto, 1978).

The First Order Models allow the use of simple inputs but do not generally result in accurate prediction of digester performance. Models based on Monod kinetic expressions result in accurate predictions but they generally require very many input parameters, some of which are difficult to determine without the aid of computer simulations. Conto is based models combine the advantages of simplified inputs of the First Order Models with the good predictive ability of the Monod based Models. These models will, however, not predict process failure due to inhibition of bacterial population.

To reduce the number of input parameters while maintaining high predictive ability a simplified Monod Kinetic Model was developed (Hill, 1983). This was

Corresponding Author: Echiegu, E.A., Department of Agricultural and Bioresources Engineering, University of Nigeria, Nsukka, Nigeria 
achieved by reducing the waste into its organic base, i.e., Biodegradable Volatile Solids (BVS) which are independent of waste type. Since many of the parameters predicted using the so called comprehensive models are hardly monitored on a continuous basis as performance indicators in anaerobic digesters, there is a serious doubt as to whether the advantages gained are worth all the computational effort.

In this study, a two-culture two-substrate system together with a modified Monod kinetic expression was employed in the study of dynamic response of continuous mix anaerobic reactors operating on dairy manure under a diurnally cyclic mesophylic and psychrophilic temperature ranges.

\section{MODEL DEVELOPMENT}

\subsection{Growth Limiting Substrate}

The two bacterial culture considered in this model are the acidogens and methanogens. Accordingly, different growth limiting substrates need to be identified. From the point of view of microbiology and biochemistry of anaerobic digestion process, the growth limiting substrate for acid formers is assumed to be the Biodegradable Volatile Solids (BVS) while that of acid formers is assumed to be the Volatile Fatty Acids (VFA). The biodegradability of a given substrate $\left(\beta_{0}\right)$ is the fraction of the raw substrate that is convertible to a useful utilizable form by microorganisms. In terms of Volatile Solids (VS) biodegradability can be defined as follows Equation 1:

$$
\beta_{o}=\lim _{\theta \rightarrow \infty}\left[\frac{\text { gramVS destroyed }}{\text { gramVS added }}\right]
$$

Where:

$\beta_{o}=$ The biodegradability constant,

$\theta=$ The retention time (d) and

$V S=$ The volatile solids concentration $(\mathrm{mg} / \mathrm{L})$

For a waste of known influent Total Volatile Solid (TVS), the influent biodegradable VS is given by Equation 2:

$$
S_{i}=\beta_{o}(T V S)
$$

Where:

$S_{i}=$ The influent biodegradable volatile solid concentration $(\mathrm{g} / \mathrm{L})$

TVS $=$ The Total Volatile Solid $(\mathrm{g} / \mathrm{L})$
For stoichiometric purposes, glucose will be assumed as the soluble substrate.

\subsection{Assumptions}

The BVS will be assumed to be the growth limiting substrate for accidogenic bacteria while the VFA (notably volatile acetic acid) is assumed to be the growth limiting substrate for methanogenic bacteria. Other assumptions made in the model include: Continuous feeding, continuous mixing, negligible cell mass concentration in the influent material (raw substrate), two culture-two substrate system, inhibition of both cultures due to VFA and negligible effect of other inhibitory agents such as ammonium.

\subsection{Substrate Mass Balance}

\subsubsection{Biodegradable Volatile Solids:}

$\left[\begin{array}{c}\text { Rate of } \\ \text { Accumulation }\end{array}\right]=\left[\begin{array}{c}\text { Input } \\ \text { Rate }\end{array}\right]$
$-\left[\begin{array}{c}\text { Output } \\ \text { Rate }\end{array}\right]-\left[\begin{array}{c}\text { Rate of } \\ \text { Utilization }\end{array}\right]$

Mathematically Equation 3 to 5:

$V \frac{d S}{d t}=Q S_{i}-Q S_{e}-\left[\frac{\mu_{a X a}}{Y_{a}}\right] V$

Or:

$\frac{d S}{d t}=\frac{Q}{V}\left(S_{i}-S_{e}\right)-\left[\frac{\mu_{a X a}}{Y_{a}}\right]$

Substituting for $\theta=V / Q$ yields Equation 6:

$\frac{d S}{d t}=\frac{S_{i}-S_{e}}{\theta}-\frac{\mu_{a X a}}{Y_{a}}$

Where:

$d s / d t=$ The rate of BVS accumulation (mg/L.d)

$V \quad=$ The reactor volume $(\mathrm{L})$

$S_{e} \quad=$ The effluent BVS concentration $(\mathrm{g} / \mathrm{L})$

$\theta \quad=$ The hydraulic retention time $V / Q(\mathrm{~d})$

$\mu_{\mathrm{a}} \quad=$ The specific growth rate of acid bacteria $(1 / \mathrm{d})$

$X_{a}=$ The concentration of acid bacteria $(\mathrm{g} / \mathrm{L})$

$Y_{a}=$ The growth yield coefficient of acid Bacteria $(\mathrm{g}$ cell/g BVS) 


\subsubsection{Volatile Fatty Acid:}

$\left[\begin{array}{c}\text { Rate of } \\ \text { Accumulation }\end{array}\right]=\left[\begin{array}{c}\text { Input } \\ \text { Rate }\end{array}\right]-\left[\begin{array}{c}\text { Output } \\ \text { Rate }\end{array}\right]$

$+\left[\begin{array}{c}\text { Rate of } \\ \text { BVS Conversion }\end{array}\right]-\left[\begin{array}{c}\text { Rate of } \\ \text { Utilization }\end{array}\right]$

Mathematically Equation 7 to 9:

$V \frac{d A}{d t}=Q A_{i}-Q A_{e}+V\left[\frac{\mu_{a} X_{a}}{Y_{a}}\right]\left(1-Y_{a}\right)-V\left[\frac{\mu_{m} X_{m}}{Y_{m}}\right]$

Or:

$$
\frac{d A}{d t}=\frac{Q}{V}\left(A_{i}-A_{e}\right)+\left[\frac{\mu_{a} X_{a}}{Y_{a}}\right]\left(1-Y_{a}\right)\left[\frac{\mu_{m} X_{m}}{Y_{m}}\right]
$$

Substituting for $\theta=V / Q$ yields Equation 10:

$$
\frac{d A}{d t}=\frac{A_{i}-A_{e}}{\theta}+\left[\frac{\mu_{a} X_{a}}{Y_{a}}\right]\left(1-Y_{a}\right)\left[\frac{\mu_{m} X_{m}}{Y_{m}}\right]
$$

Where:

$d A / d t=$ The rate of VFA accumulation (mg/L.d)

$A_{i} \quad=$ The influent VFA concentration $(\mathrm{g} / \mathrm{L})$

$A_{e} \quad=$ The effluent VFA concentration $(\mathrm{g} / \mathrm{L})$

$\mu_{\mathrm{m}} \quad=$ The specific growth rate of methane forming bacteria $(1 / \mathrm{d})$

$X_{m} \quad=$ The concentration of methane forming bacteria $(\mathrm{g} / \mathrm{L})$

$Y_{m} \quad=$ The growth yield coefficient of methane forming Bacteria ( $\mathrm{g}$ cell/g BVS)

\subsection{Cell Mass Balance}

\subsubsection{Acid Formers:}

\section{$\left[\begin{array}{c}\text { Net Rate of Cell } \\ \text { Mass Accumulation }\end{array}\right]=\left[\begin{array}{c}\text { Cell Mass } \\ \text { Inflow Rate }\end{array}\right]$ \\ $-\left[\begin{array}{c}\text { Outflow Rate } \\ \text { of Biomass }\end{array}\right]+\left[\begin{array}{c}\text { Biomass } \\ \text { Generation Rate }\end{array}\right]$}

Mathematically Equation 11 to 14:

$V \frac{d X_{a}}{d t}=Q X_{a_{i}}-Q X_{a}+V\left(\mu_{a}-\kappa_{d_{a}}\right) X_{a}$

$\frac{d X_{a}}{d t}=\frac{Q}{V}\left(X_{a_{i}}-X_{a_{e}}\right)+\left(\mu_{a}-\kappa_{d_{a}}\right) X_{a}$

Substituting for $\theta=V / Q$ and assumingthe influent acid for cell mass concentration $\left(X_{a i}\right)=$ zero:

$\frac{d X_{a}}{d t}=\left(\mu_{a}-\kappa_{d_{a}}-\frac{1}{\theta}\right) X_{a_{e}}$

Where:

$d X_{a} / d t=$ The rate of accumulation of cell mass of acid forming bacteria (mg/L.d)

$K_{d a}=$ The endogenous decay coefficients of acid forming bacteria $(1 / \mathrm{d})$

\subsubsection{Methane Formers:}

$\left[\begin{array}{l}\text { Net Rate of } \\ \text { Cell Mass } \\ \text { Accumulation }\end{array}\right]=\left[\begin{array}{l}\text { Cell Mass } \\ \text { Inflow } \\ \text { Rate }\end{array}\right]$
$-\left[\begin{array}{l}\text { Outflow } \\ \text { Rate of } \\ \text { Biomass }\end{array}\right]+\left[\begin{array}{l}\text { Biomass } \\ \text { Generation } \\ \text { Rate }\end{array}\right]$

Mathematically Equation 15 to 17 :

$V \frac{d X_{m}}{d t}=Q X_{m_{i}}-Q X_{m_{e}}+V\left(\mu_{m}-\kappa_{d_{m}}\right) X_{m}$

Or:

$\frac{d X_{m}}{d t}=\frac{Q}{V}\left(X_{m_{i}}-X_{m_{e}}\right)+\left(\mu_{m}-\kappa_{d_{m}}\right) X_{m}$

Substituting for $\theta=V /$ :

$\frac{d X_{m}}{d t}=\left(\mu_{m}-\kappa_{d_{m}}-\frac{1}{\theta}\right) X_{m}$

Where:

$d X_{m} / d t=$ The rate of accumulation of cell mass of methane forming bacteria $(\mathrm{mg} / \mathrm{L} . \mathrm{d})$

$K d_{m} \quad=$ The endogenous decay coefficients of methane forming bacteria (1/d) 


\subsection{Growth Rate Coefficient}

Several kinetic expressions showing the relationships between growth rate and substrate utilization exist. The one adopted in this model is as follows:

$$
\mu=\left[\frac{\mu_{\max }}{\frac{K_{s}}{S_{l}}+1+\frac{S_{t}}{K_{i}}}\right]
$$

Where:

$\mu \quad=$ The specific growth rate $(1 / \mathrm{d})$,

$\mu_{\max }=$ The maximum specific growth rate $(1 / \mathrm{d})$

$K_{s}=$ The half velocity coefficient $(\mathrm{g} / \mathrm{L})$

$S_{l}=$ The concentration of growth limiting substrate $(\mathrm{g} / \mathrm{L})$

$S_{t} \quad=$ The concentration of inhibitory toxic substrate $(\mathrm{g} / \mathrm{L})$

$K_{i} \quad=$ The inhibition coefficient $(\mathrm{g} / \mathrm{l})$

For acidogens, the growth limiting substrate is the Biodegradable Volatile Solids (BVS) while the inhibitory substrate is the Volatile Fatty Acid (VFA). For the methanogens, the VFA is both the growth limiting and inhibitory substrate. Adapting Equation 19 for the growth rate expressions of acid and methane formers, the following respective Equation result:

$$
\mu_{a}=\left[\frac{\mu_{\max _{a}}}{\frac{K_{s_{a}}}{S_{l}}+1+\frac{A}{K_{i_{a}}}}\right]
$$

$$
\mu_{m}=\left[\frac{\mu_{\text {max }_{m}}}{\frac{K_{s_{m}}}{S_{l}}+1+\frac{A}{K_{i_{m}}}}\right]
$$

where, $A_{1}$ is the concentration of the growth limiting substrate for methogens ( $\mathrm{g}$ VFA/L).

In this study, the maximum specific growth rate $\left(\mu_{m}\right)$ is a function of temperature only. Chen and Hashimoto (1981) gave the following relationships between maximum specific growth rate and Temperature $\left(\mathrm{T}^{\circ} \mathrm{C}\right)$ :

$$
\mu_{\max }=\left[\begin{array}{ll}
0.0186 T-0.325 & \left(30^{\circ} \mathrm{C} \leq T \leq 45^{\circ} \mathrm{C}\right) \\
0.0048 T+0.298 & \left(45^{\circ} \mathrm{C}<T \leq 60^{\circ} \mathrm{C}\right) \\
0.0200 T+1.770 & \left(60^{\circ} \mathrm{C}<T \leq 65^{\circ} \mathrm{C}\right)
\end{array}\right]
$$

Echiegu (2013) presented the following function which suggested that the diurnal (hourly) dry bulb temperature can be represented by a sinusoid with an angular frequency of $0.261799 \mathrm{~h}^{-1}$ and a phase angle of 1.8 radians:

$T_{h}=T_{\text {ave }}+T_{\text {amp }}\left[\begin{array}{l}\sin 0.261799(h+13) \\ +\sin 0.261799\left(\frac{h+13}{3}\right)^{2}\end{array}\right]$

Where:

$T_{h}=$ The hourly dry bulb temperature $\left({ }^{\circ} \mathrm{C}\right)$

$T_{\text {ave }}=$ The mean daily temperature $\left({ }^{\circ} \mathrm{C}\right)$

$T_{\text {amp }}=$ The mean daily temperature amplitude which is half the difference between the maximum and minimum daily temperature

$h=$ The hour of the day $(1.00 \mathrm{am}=$ hour No 1$)$

By Combining Equation 22 and 23 with the kinetic growth rate Equation 20 and 21, the growth rate coefficients for the acidogens and methanogens under diurnally cyclic temperature environment was derived and used in the model. Two diurnally cyclic temperature ranges $\left(20-40^{\circ} \mathrm{C}\right.$ and $\left.15-15^{\circ} \mathrm{C}\right)$ were used in the model.

Although un-ionized volatile acid is generally recognized as the inhibitory form of VFA in anaerobic digestion, total rather than un-ionized volatile acids have been used in dynamic modeling with good result (Hill and Nordstedt, 1980; Hill, 1982; 1983). The inhibition coefficient in this case is usually in terms of total volatile acid instead of un-ionized VFA. However, at $\mathrm{pH}$ between 5.5 and 8.0, the concentration of un-ionized VFA is usually negligible.

\subsection{Gas Production}

With glucose (molecular weight $=180 \mathrm{~g} / \mathrm{mole}$ ) assumed as the biodegradable volatile solid for stiochiometric purposes, the COD of the glucose can be determined from the following oxidation Equation 24:

$\mathrm{C}_{6} \mathrm{H}_{12} \mathrm{O}_{6}+6 \mathrm{O}_{2} \rightarrow 6 \mathrm{CO}_{2}+6 \mathrm{H}_{2} \mathrm{O}+\Delta \mathrm{E}$

Thus, $192 \mathrm{~g}(6 \times 16 \times 2)$ of oxygen is required for complete oxidation of one mole (180 g) of glucose. The theoretical oxygen demand for glucose is therefore $192 \mathrm{~g}$ $\mathrm{O}_{2} / 180 \mathrm{~g}$ glucose (or $1.067 \mathrm{~g} \mathrm{O} \mathrm{O}_{2} / \mathrm{g}$ glucose). The 
conversion of glucose to methane and carbon dioxide can be represented by the following Equation 25:

$$
\mathrm{C}_{6} \mathrm{H}_{12} \mathrm{O}_{6}+\rightarrow 3 \mathrm{CO}_{2}+3 \mathrm{CH}_{4}
$$

Thus, $0.267[(3 \times 16) / 180] \mathrm{g}$ of methane is produced from one gram of glucose. Hence, the amount of methane produced per gram of COD stabilized is 0.25 $\mathrm{g}\left[0.267 \mathrm{~g} \mathrm{CH}_{4} / 1.067 \mathrm{~g} \mathrm{COD}\right]$. Since one mole of gas occupies a volume of $22.4 \mathrm{~L}$ at Standard Temperature and Pressure (STP), this is equivalent to $0.35 \mathrm{~L} \mathrm{CH}_{4} / \mathrm{g}$ COD $[(0.25 \times 22.4) / 16]$.

If the ratio of biodegradable COD to BVS of substrate is $R$, the volume of gas that would be produced from the conversion of $1.0 \mathrm{~g}$ of BVS would be $0.35 R$. The volumetric methane production $\left(\gamma_{v}\right)$ and methane yield $\left(\gamma_{g}\right)$ can then be computed as follows Equation 26 and 27:

$$
\begin{aligned}
& \gamma_{v}=0.35 R\left(\frac{\left(S_{i}-S_{e}\right)}{\theta}\right) \\
& \gamma_{g}=0.35 R\left(\frac{\left(S_{i}-S_{e}\right)}{S_{i}}\right)
\end{aligned}
$$

Where:

$\gamma_{v}=$ The volumetric methane production (L/L.d)

$\gamma_{\mathrm{g}}=$ The methane yield (L/g VS added)

$R=$ The ratio of biodegradable COD to BVS of substrate

\subsection{Solid Reduction and Treatment Efficiency}

Volatile Solids Reduction (VSR) and treatment efficiency $(\eta)$ were computed as follows Equation 28 and 29:

$$
\begin{gathered}
V S R=\frac{\left(S_{T_{i}}-S_{T_{e}}\right)}{S_{T_{i}}} \\
\eta=\left[\frac{S_{T_{i}}-S_{T_{e}}}{S_{T_{i}}}\right] \times 100
\end{gathered}
$$

Where:

$S_{T o}=$ The influent TVS concentration $(\mathrm{mg} / \mathrm{L})$

$S_{T i}=$ The effluent TVS, concentration $(\mathrm{mg} / \mathrm{L})$

$\eta=$ The treatment efficiency $(\%)$

\section{DETERMINATION OF MODEL PARAMETERS}

\subsection{Yield Coefficient}

The Yield coefficients were determined from the stoichiometry of the process. An elemental analysis of dairy manure indicated that its chemical composition can be represented by $\mathrm{C}_{6} \mathrm{H}_{12} \mathrm{NO}_{2}$. Hill (1985) has also noted that dairy, beef and poultry manure have similar carbon to nitrogen ratio. They also noted that organic waste is converted to soluble organics (presumed as glucose) on one to one weight and volume basis. The conversion of glucose (assumed as the soluble organic for stoichiometric purposes) to VFA may be described as follows (Jeyanayagam, 1986).

\subsubsection{Acidogenesis:}

$$
\begin{aligned}
& \text { Glucose }+ \text { Ammonia } \rightarrow \text { Cells }+ \text { Acetate } \\
& + \text { Propionate }+ \text { Butyrate }+ \text { Carbon Dioxide } \\
& \mathrm{C}_{6} \mathrm{H}_{12}+\mathrm{O}_{6}+0.1115 \mathrm{~N}_{4}^{+}+1.05 \mathrm{H}^{+}+1.16_{e}^{-} \\
& \rightarrow 0.1115 \mathrm{C}_{5} \mathrm{H}_{7} \mathrm{NO}_{2}+0.744 \mathrm{CH}_{3} \mathrm{COOH} \\
& +0.5 \mathrm{CH}_{3} \mathrm{CH}_{2} \mathrm{COOH}+0.5 \mathrm{CH}_{3} \mathrm{CH}_{2} \mathrm{CH}_{2} \mathrm{COOH} \\
& +0.454 \mathrm{CO}_{2}+1.38 \mathrm{H}_{2} \mathrm{O}
\end{aligned}
$$

\subsubsection{Propionate Hydrogenesis Equation 32:}

$$
\begin{aligned}
& \text { Propionic Acid }+ \text { Ammonia } \rightarrow \text { Cells } \\
& + \text { Acetic Acid }+ \text { Hydrogen }+ \text { Carbon Dioxide } \\
& \mathrm{CH}_{3} \mathrm{CH}_{2} \mathrm{COOH}+0.0458 \mathrm{NH}_{4}^{+}+0.0458_{e}^{-} \\
& +1.786 \mathrm{H}_{2} \mathrm{O} \rightarrow 0.0458 \mathrm{C}_{5} \mathrm{H}_{7} \mathrm{NO}_{2} \\
& +0.924 \mathrm{CH}_{3} \mathrm{COOH}+0.924 \mathrm{CO}_{2}+2.87 \mathrm{H}_{2}
\end{aligned}
$$

\subsubsection{Butyrate Hydrogenesis Equation 34:}

$$
\begin{aligned}
& \text { Butric Acid + Ammonia } \rightarrow \text { Cells } \\
& + \text { Acetic Acid + Hydrogen } \\
& \mathrm{CH}_{3} \mathrm{CH}_{2} \mathrm{CH}_{2} \mathrm{COOH}+0.0545 \mathrm{~N}_{4}^{+}+1.84 \mathrm{H}_{2} \mathrm{O} \rightarrow \\
& 0.0545 \mathrm{C}_{5} \mathrm{H}_{7} \mathrm{NO}_{2}+1.86 \mathrm{CH}_{3} \mathrm{COOH}+2.04 \mathrm{H}_{2}
\end{aligned}
$$

In Equation 31, 33 and 35, the chemical composition of bacteria is assumed to be $\mathrm{C}_{5} \mathrm{H}_{7} \mathrm{NO}_{2}$ with a molecular weight of $113 \mathrm{~g} / \mathrm{mole}$. The nitrogen source for the reactions represented in the equations as ammonium is the hydrolysis of raw substrate which is catalyzed by 
extracellular enzymes. In the case of dairy manure, the reaction is represented by the following Equation:

$$
\mathrm{C}_{6} \mathrm{H}_{13} \mathrm{NO}_{5}+\mathrm{H}_{2} \mathrm{O}+\mathrm{H}^{+} \rightarrow \mathrm{C}_{6} \mathrm{H}_{12} \mathrm{O}_{6}+\mathrm{NH}_{4}^{+}
$$

Equation 30 to 36 show that the conversion of one mole glucose to volatile acids results in the production of 0.1115 moles of cells and 0.5 moles each of propionate and butyrate. The conversion of one mole of propionate and butyrate in turn results in the production of 0.0458 and 0.0545 moles of cells, respectively. The total number of moles of bacterial cells formed as a result of the breakdown of one mole of glucose is 0.312 moles [0.1115+ $(0.0458+0.0545) / 0.5]$. Hence, the yield coefficient for acid formers $\left(Y_{a}\right)$ is calculated from Equation 37:

$Y_{a}=\frac{(0.312 \text { mol cell } \times 113 \mathrm{~g} \text { cell per mol cell })}{\text { mole glucose } \times 180 \mathrm{~g} / \mathrm{mol}}$

$=0.196$ g cell per $g$ glucose

This is equivalent to Equation 38:

$Y_{a}=(0.196 \mathrm{~g}$ cell $/ \mathrm{g}$ glucose $)$

$\times(1.067 \mathrm{~g}$ glucose / $\mathrm{g}$ BCOD $)$

$=0.209$ gramcell per gram $C O D$

The yield in terms of BVS is computed as follows Equation 39:

$$
Y_{a}=(0.209 \mathrm{~g} \text { cell / } g \text { BCOD }) \times(R g B C O D / g B V S)
$$

For this model, the ratio of BCOD to BVS of dairy manure $(R)$ was 1.51 .

\subsubsection{Methanogenesis}

In order to compute the yield coefficient of methane bacteria $\left(Y_{m}\right)$, acetic acid (mol wt. $=60$ $\mathrm{g} / \mathrm{mole}$ ) was assumed as the substrate. The chemical reaction is as follows Equation 40:

$$
\begin{aligned}
& \mathrm{CH}_{3} \mathrm{COOH}+0.0227 \mathrm{NH}_{3} \rightarrow 0.0227 \mathrm{C}_{5} \mathrm{H}_{7} \mathrm{NO}_{2} \\
& +0.943 \mathrm{CH}_{4}+0.943 \mathrm{CO}_{2}+0.069 \mathrm{H}_{2} \mathrm{O}
\end{aligned}
$$

The conversion of one mole of acetic acid results in the formation of 0.0227 moles of cells. Thus, the yield coefficient of methane bacteria is equal to $0.043 \mathrm{~g}$ cell $/ \mathrm{g}$ VFA [i.e., $\{(0.0227$ mole cell $) \times(113 \mathrm{~g} /$ mole cell $)\} /\{1$ mole acetic acid $) \times(60 \mathrm{~g} /$ mole acetic acid $)\}]$.

\subsection{Biodegradability Constant}

Biodegradability was determined in this study, using the method of (Echiegu and Ghaly, 1993) by plotting volatile solid destruction versus the reciprocal of hydraulic retention time and extrapolating to the Y-axis (Fig. 1).

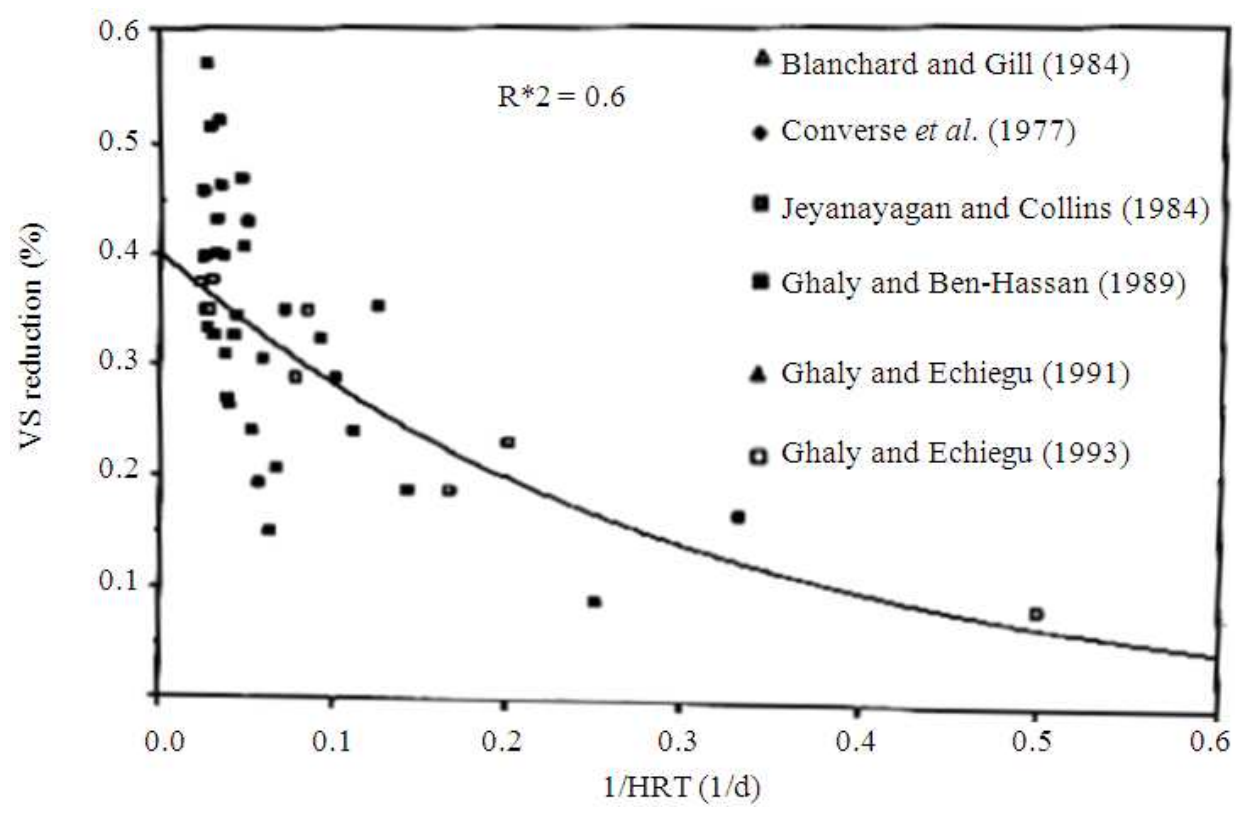

Fig. 1. Determination of biodegradability (VS basis) 
The interception on this axis is, by definition, the biodegradability of the waste. The data used for the study were the dairy manure data of (Converse et al., 1977; Blanchard and Gill, 1984; Jeyanayagam and Collins, 1984; Ghaly and Ben-Hassan, 1989; Ghaly and Echiegu, 1992; 1993). The estimated biodegradability constant on the basis of volatile acid was 0.4 .

\subsection{Endogenous Decay Coeficient}

A value of $K_{s}$ equal to $10 \%$ of the maximum specific growth rate was assumed in the model.

\subsection{Half Velocity and Inhibition Constants}

These were determined by computer iteration using the best fit for actual daily biogas production data obtained from experiment.

\section{MODEL IMPLEMENTATION}

The set of non-linear Equation [Equation 6, 10, 14, 18, 20 and 21] were solved using Forth Order Runge-Kutta method (Gupta, 1995). Input parameters included the influent and total volatile solids and VFA concentrations as well as the reactor volume and hydraulic retention time. The initial cell mass concentration was considered to be the Volatile Suspended Solids (VSS) concentration of the seed material. Since this comprises the acid and methane formers, a value equal to half of the total influent VSS was used as the initial concentration of each of acid and methane formers.

\section{MODEL VALIDATION}

The results of the simulation were compared to an experimental of a continuous-mix anaerobic reactor operated on dairy manure under two diurnal temperature ranges of $20-40^{\circ} \mathrm{C}$ and $15-25^{\circ} \mathrm{C}$. Two samples of manure of total solids contents of 6.4 and $3.5 \%$ respectively and four levels of HRT (10 days, 15 days, 20 days and 25 days) were used in the study. The ratio of BCOD to BVS of dairy manure $(R)$ was determined to be 1.51 on the average for the two manure samples and this was used in the simulation.

\section{RESULTS AND DISCUSSIONS}

Typical results of the kinetic model are shown in Fig. 2 and 3. Figure 2 shows the result obtained using a manure of $6.4 \%$ TS for a reactor operated at 20 days
HRT while Fig. 3 shows the result for 10 days HRT. For the $20-40^{\circ} \mathrm{C}$ temperature cycle and $20 \mathrm{~d}$ HRT, the predicted effluent Volatile Solids (VS) concentration declined rapidly down to about $200 \mathrm{mg} \mathrm{L}^{-1}$ within the first 18 days and then remained fairly constant (Fig. 2a). The biogas production rate and the concentration of acid bacteria were predicted to rise rapidly, that of methane formers was predicted to decline slightly while that of VFA rose slightly over the prediction period of 60 days. Overall, after some initial instability, steady state was achieved after about 18 days.

At the operating temperature cycle of $15-25^{\circ} \mathrm{C}$, HRT of 20 days and influent TVS of $6.4 \%$, initial instability was predicted within the first ten days with the VFA and acid bacterial cell mass concentration as well as biogas production rising to varying degrees while the VS and methane bacteria cell mass concentrations fell within the same period (Fig. 2b). After about the tenth day, the VS and VFA concentrations were predicted to increase gradually while biogas production and the cell mass concentrations of acid and methane bacteria were predicted to decrease.

At 10 days HRT, both the predicted VS and methane bacterial cell mass concentration declined within the first 20 days after which the effluent VS increased while the continued to decrease (Fig. 3a). The predicted concentration of acid bacteria and VFA as well as the biogas production increased initially up to about the 20th day after which these parameters declined steadily.

At the operating temperature of $15-25^{\circ} \mathrm{C}, \mathrm{HRT}$ of 10 days and influent VS of $6.4 \%$, slight decreases in VS, VFA and methane bacteria cell mass concentrations were predicted for the first five days (Fig. 3b). A slight increase in biogas production was also predicted for the same period. For the remaining period, the VS and VFA concentrations were predicted to increase while all other parameters were predicted to decrease.

The predicted initial fluctuation in parameters is an indication of the instability which accompanies changes in reactor operating conditions. Following this unstable period, was predicted an asymptotic decrease in effluent VS concentration and an increase in biogas production for the 20 day HRT. The predicted and experimental results indicated that the digester was healthy at 20 day HRT. For the 10 day HRT, the prediction indicated that the unstable period was followed by an initial increase in biogas production and the concentration of acid formers as 
well as decrease in the predicted effluent TVS and VFA concentration. After predicted methane bacterial cells mass concentration this period, a reversal in the predicted trends of the parameters was observed. The predicted and experimental results for the 10 day HRT indicated sick digester.

Typical results for the manure of $3.5 \%$ TS content are shown in Fig. 4. At 20 days HRT and operating diurnal temperature cycle of $20-40^{\circ} \mathrm{C}$ (Fig. 4a), both the VS and methane bacteria concentrations were predicted to decline sharply within the first two days. After this period, the methane bacteria population continued to decrease gradually until the end of the prediction period while the VS concentration rose after the 27th day. The predicted acid bacteria population and the biogas production rate also rose sharply within the first two days and then gradually up to the 27 th day after which there was a steady decline in the two parameters. The VFA was predicted to decline slightly and then rose gradually.

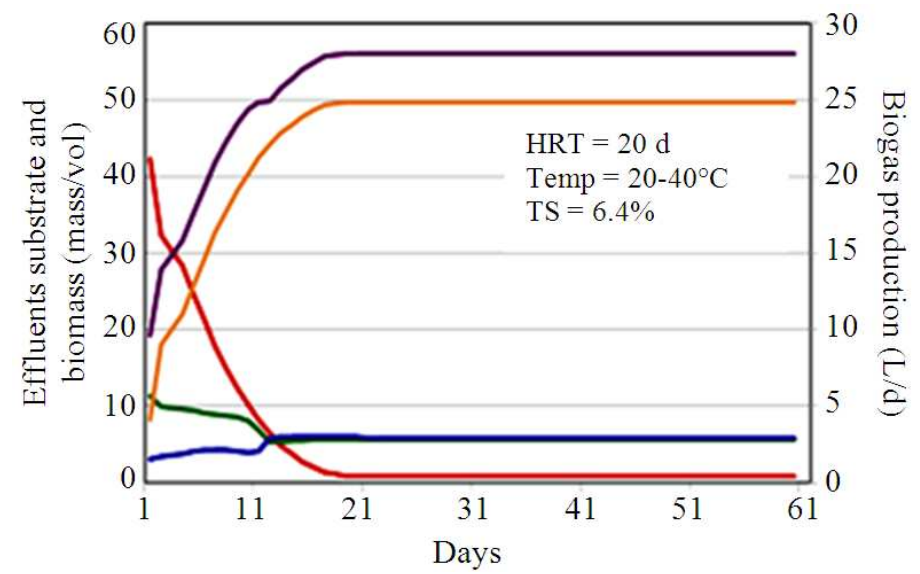

(a)
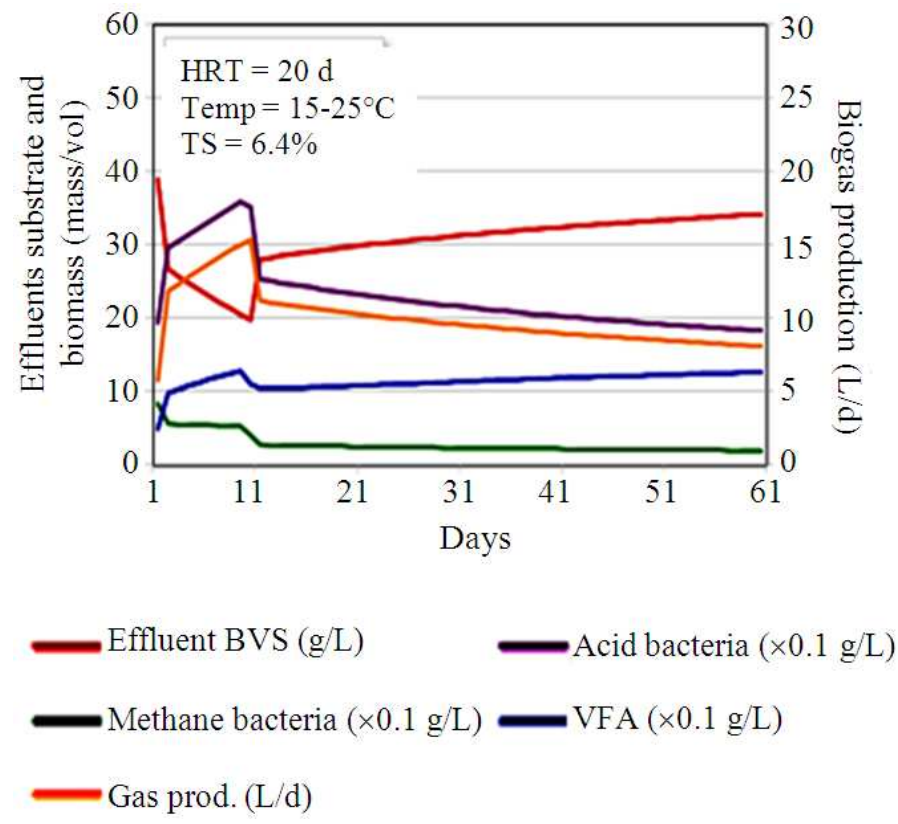

(b)

Fig. 2. Predicted effluent volatile solids, VFA, acid bacteria and methane bacteria cell mass concentrations and biogas production at 20 day HRT using manure of $6.4 \%$ TS and two diurnal temperature cycles 
At the $15-25^{\circ} \mathrm{C}$ cycles, there was a slight steady value for all the parameters up to the 15th day after which the VS and VFA increased while all other parameters decreased steadily indicating reactor failure.

Typical comparison between the predicted and actual biogas production rates is shown in Fig. 5 and 6. The results showed that a fairly accurate prediction in biogas production $\left(\mathrm{R}^{2}=0.8\right)$ under the indicated diurnally cyclic operating temperature condition. A comparison of the actual and predicted effluent VS concentration, methane yield, treatment efficiency and cell mass concentration showed a fairly accurate prediction $\left(\mathrm{R}^{2}\right.$ varying from 0.7 to 0.9 ) as shown in Table 1 except for cell mass concentration where the predicted values were very much lower that actual values. This result showed that Volatile Suspended Solids (VSS), which was used as the actual (experimental) cell mass concentration, was not a good indicator of active cell mass bacterial cell mass concentration in an aerobically digested dairy manure.

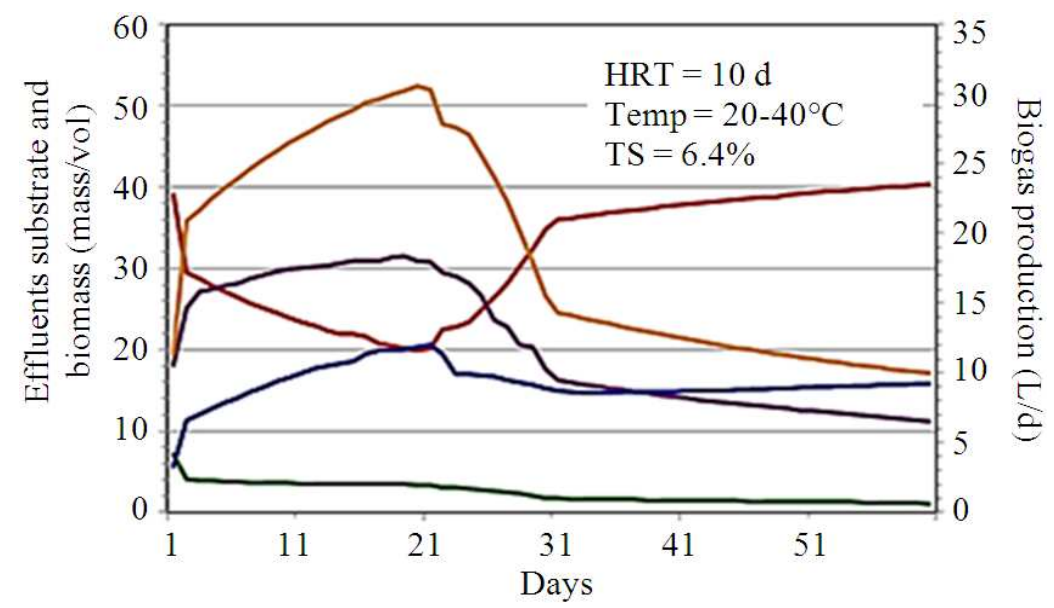

(a)

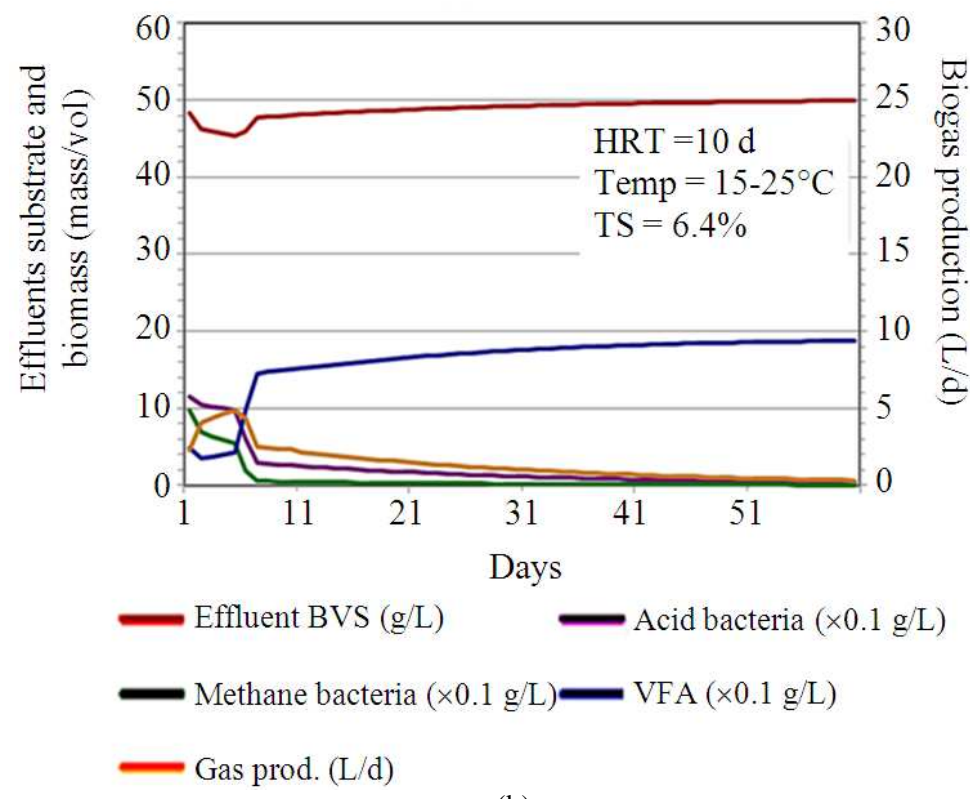

(b)

Fig. 3. Predicted effluent volatile soilds, VFA, acid bacteria and methane bacteria cell mass concentrations and biogas production at 10 day HRT using manure of $6.4 \%$ TS and two diurnal temperature cycles 
Echiegu, E.A. and A.E. Ghaly / American Journal of Biochemistry and Biotechnology 10 (2): 130-142, 2014

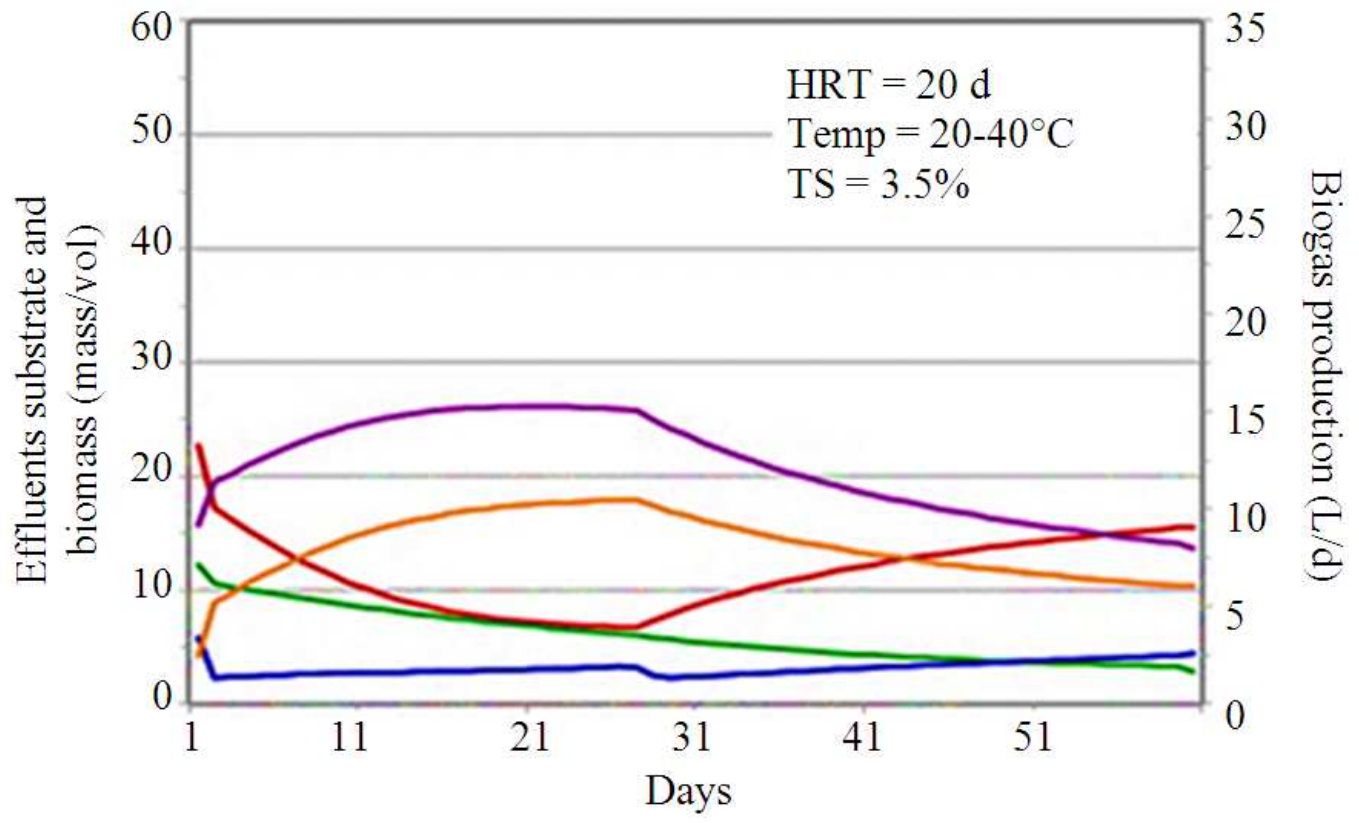

(a)
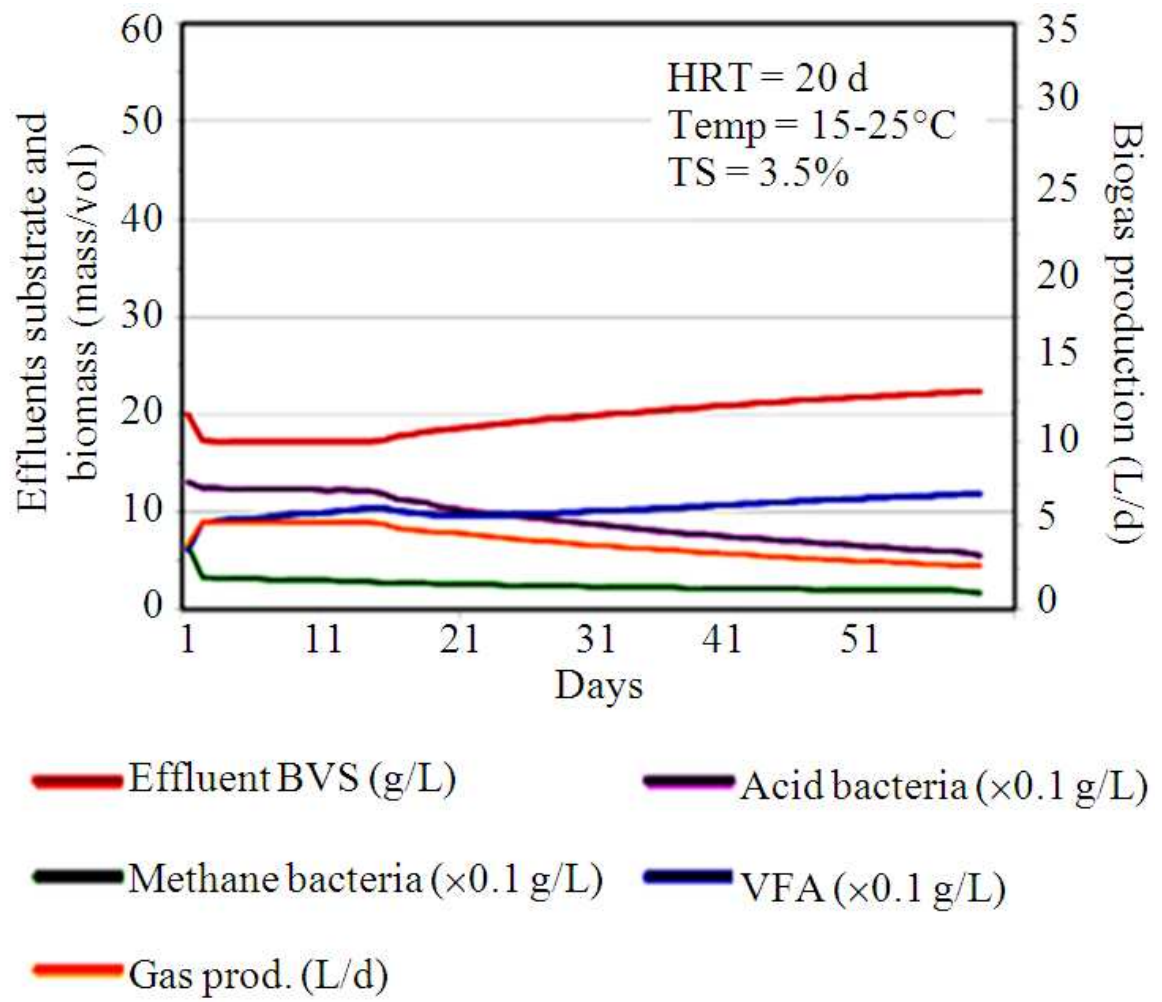

(b)

Fig. 4. Predicted effluent volatile soilds, VFA, acid bacteria and methane bacteria cell mass concentrations and biogas production at 20 day HRT using manure of $3.5 \%$ TS and two diurnal temperature cycles 
Echiegu, E.A. and A.E. Ghaly / American Journal of Biochemistry and Biotechnology 10 (2): 130-142, 2014

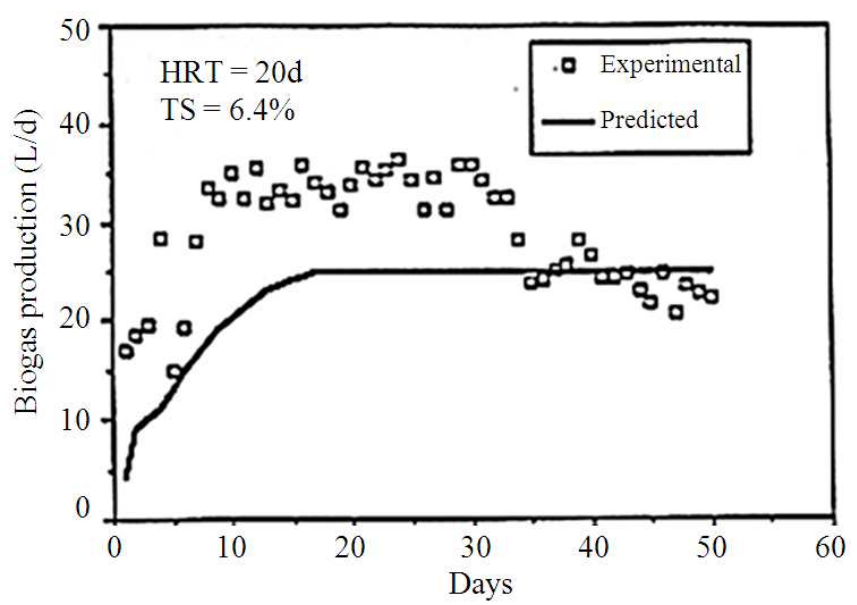

(a)

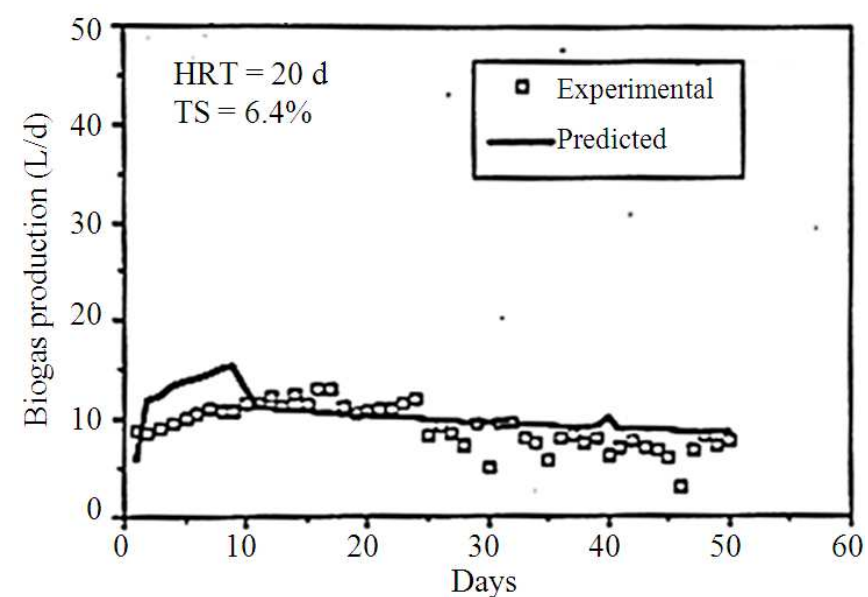

(b)

Fig. 5. Typical result of prediction and actual biogas production

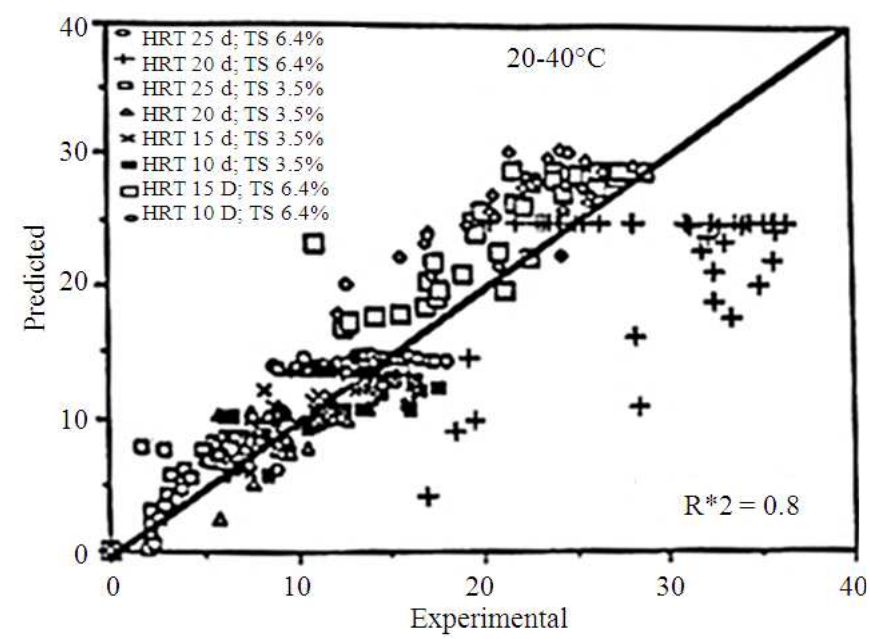

(a) 


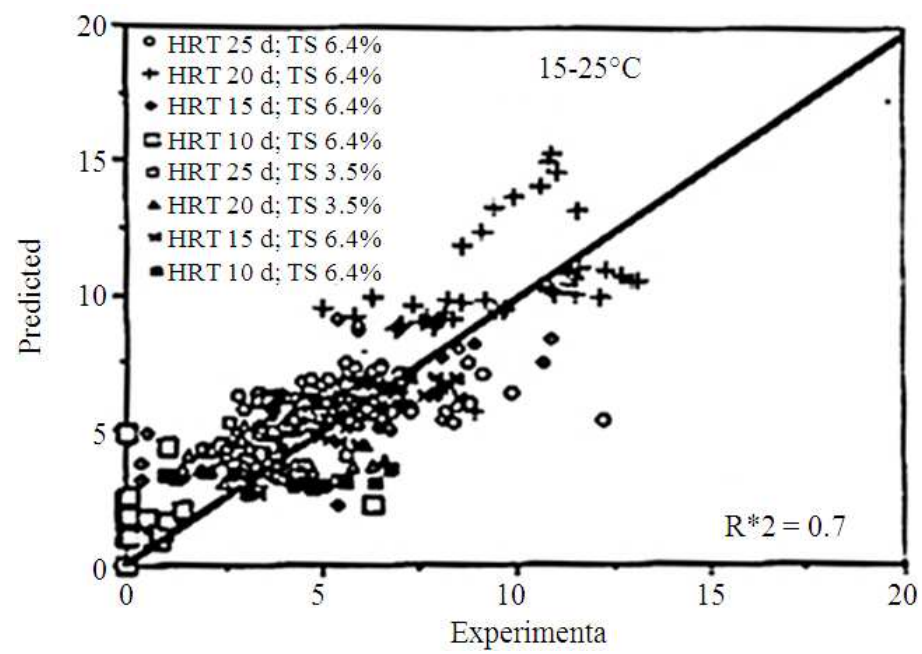

Fig. 6. Comparison of the predicted and actual biogas production (TS basis)

Table 1. $\mathrm{R}^{2}$ values from the comparison of actual and predicted performance parameters

\begin{tabular}{ll}
\hline Parameter & $\mathrm{R}^{2}$ value \\
\hline Effluent volatile solids & 0.8 \\
Methane yield & 0.9 \\
Treatment efficiency & 0.7 \\
Cell mass concentration & 0.3 \\
\hline
\end{tabular}

The average maximum specific growth rate was estimated to be $0.251 / \mathrm{d}$. This was lower than values estimated by other researchers (Siegrist et al., 2002) and the inhibition coefficients for the acid and methane (Chen, 2010) for digesters operating at a constant mesophilic temperature which may be attributed to the effect of diurnally cyclic temperature. Formers were predicted to be fairly constant at about 11.0 and $5.0 \mathrm{~g}$ $\mathrm{L}^{-1}$, respectively. Again this is higher than the value of 0.05 to $1.0 \mathrm{~g} \mathrm{COD} / \mathrm{L}$ given by (Chen, 2010) for amino acid fermentation and long chain fatty acid degradation, respectively indicating inhibition problem under diurnally cyclic temperature environment.

The half velocity coefficient for methane bacteria was predicted to be constant at $2.0 \mathrm{~g} \mathrm{~L}^{-1}$ while that of acid bacteria was predicted to vary from 22.0 to $44.0 \mathrm{~g} \mathrm{~L}^{-1}$, thus, reflecting the effect of cyclic temperature.

\section{CONCLUSION}

A two-culture dynamic model which incorporated the effects of diurnally cyclic temperature was developed and used to predict the dynamic response of anaerobic reactors operated on dairy manure under two diurnally cyclic temperature ranges of $20-40^{\circ} \mathrm{C}$ and 15 $25^{\circ} \mathrm{C}$ which represent the summer and winter in Nigeria. The digesters were operated at various hydraulic retention times and solid concentrations and some useful kinetic parameters were determined. The model predicted biogas production, volatile solid reduction, methane yield and treatment efficiency with reasonable accuracy $\left(\mathrm{R}^{2}=0.70\right.$ to 0.90$)$. The model, however, under-predicted the cell mass concentration in the reactor probably because the Volatile Suspended Solid (VSS), which was used as the estimator of the actual cell mass concentration in the reactor was not a good indicator of the active cell mass concentration in anaerobic reactors operating on dairy manure.

\section{REFERENCES}

Blanchard, J.P. and T.A. Gill, 1984. Suspended-particle, fixed biomass anaerobic digesters for livestock wastes. Trans. ASAE, 27: 535-540. DOI: $10.13031 / 2013.32823$

Chen, Q., 2010. Kinetics of anaerobic digestion of selected $\mathrm{C} 1$ to $\mathrm{C} 4$ organic acids. M.Sc. Thesis, University of Missouri-Columbia.

Chen, Y.R. and A.G. Hashimoto, 1978. Kinetics of methane fermentation. Biotechnol. Bioeng. Symp., 8: 269-282.

Chen, Y.R. and A.G. Hashimoto, 1981. Energy requirements for anaerobic fermentation of livestock waste. Proceddings of the 4th International Conference on Livestock Waste, (CLW' 81), St Joseph, Michigan, USA, pp: 117-121. 
Converse, J.C., R.E. Graves and G.W. Evans, 1977. Anaerobic degradation of dairy manure under mesophilic and thermophilic temperatures. Trans. ASAE, 20: 336-340. DOI: 10.13031/2013.35552

Echiegu, E.A. and A.E. Ghaly, 1993. Kinetics of a continuous-flow no-mix anaerobic reactor. Energy Sources, $\quad$ 15: 433-449. DOI: 10.1080/00908319308909037

Echiegu, E.A., 2013. Energy relationships for the design of biogas reactors operating on animal waste. J. Agric. Eng. Technol., 20: 50-60.

Ghaly, A.E. and E.A. Echiegu, 1992. Performance evaluation of a continuous-flow no-mix anaerobic reactor operating on dairy manure. Energy Sources, 14: 113-114. DOI: 10.1080/00908319208908714

Ghaly, A.E. and E.A. Echiegu, 1993. Kinetics of a continuous-flow no-mix anaerobic reactor. Energy Sources, $\quad 15$ : 433-449. DOI: 10.1080/00908319308909037

Ghaly, A.E. and M.T. AlHattab, 2011. Effect of diurnally cyclic temperature on the performance of a continuous mix anaerobic digester. Am. J. Biochem. Biotechnol., 7: 146-162. DOI: 10.3844/ajbbsp.2011.146.162

Ghaly, A.E. and R.M. Ben-Hassan, 1989. Continuous production of biogas from dairy manure using an innovative no-mix reactor. Applied Biochem. Biotechnol., 20/21: 541-559. DOI: 10.1007/BF02936508

Gupta, S.K., 1995. Numerical Methods for Engineers. 2nd Edn., New Age International, New Delhi, ISBN-10: 8122406513, pp: 407.

Hill, D.T. and C.L. Barth, 1977. A dynamic model for simulation of animal waste digestion. J. Waste Pollut. Control Federat., 49: 2129-2143.
Hill, D.T. and R.A. Nordstedt, 1980. Modelling techniques and computer simulation of agricultural waste treatment processes. Agric. Wastes, 2: 135-156. DOI: 10.1016/01414607(80)90038-4

Hill, D.T., 1982. A comprehensive dynamic model for animal waste methanogenesis. Trans. ASAE, 25: 1374-1380. DOI: $10.13031 / 2013.33730$

Hill, D.T., 1983. Simplified Monod kinetics of methane fermentation of animal wastes. Agric. Wastes, 5: 116. DOI: 10.1016/0141-4607(83)90009-4

Hill, D.T., 1985. Practical and theoretical aspects of engineering modeling of anaerobic digestion for livestock waste utilization systems. Trans. ASAE, 28: 850-855. DOI: 10.13031/2013.32349

Jeyanayagam, S.S. 1986. Engineering analysis of Chinese-type anaerobic digester. $\mathrm{PhD}$. Thesis, Virginia Polytechnic and State University. Blacksburg.

Jeyanayagam, S.S. and E.R. Collins, 1984. Weed seed survival in a dairy manure anaerobic digester. Trans. ASABE, 27: 1518-1523. DOI: $10.13031 / 2013.32997$

Moris, G.R., 1976. Anaerobic fermentation of animal waste-a kinetic and empirical design evaluation. M.Sc. Thesis, Cornell University, Ithaca, NY.

Siegrist, H., D. Vogt, J.L. Garcia-Heras and W. Gujer, 2002. Mathematical model for MESO-and thermophilic anaerobic sewage sludge digestion. Environ. Sci. Technol., 36: 1113-1123. DOI: 10.1021/es010139p 